Journal of Agricultural Sciences
(Tarim Bilimleri Dergisi)

\title{
Genetic Diversity and Population Structure of Barley Cultivars Released in Turkey and Bulgaria using iPBS-retrotransposon and SCoT markers
}

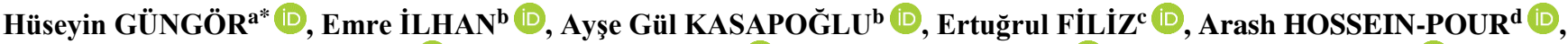

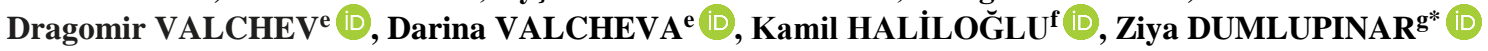 \\ ${ }^{a}$ Department of Field Crops, Faculty of Agriculture, Duzce University, 81620, Duzce, TURKEY

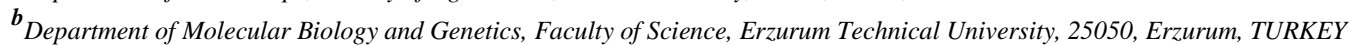 \\ ${ }^{c}$ Department of Crop and Animal Production, Cilimli Vocational School, Duzce University, 81750, Cilimli, Duzce, TURKEY \\ ${ }^{d}$ Department of Field Crops, Faculty of Agriculture, Necmettin Erbakan University, 42310, Konya, TURKEY \\ enstitute of Agriculture, Karnobat, BULGARIA

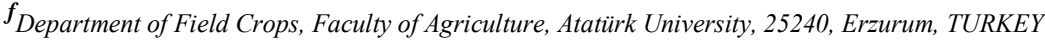 \\ ${ }^{g}$ Department of Agricultural Biotechnology, Faculty of Agriculture, Kahramanmaraş Sütçü İmam University, 46100, Kahramanmaraş, TURKEY
}

\section{ARTICLE INFO}

Research Article

Corresponding Authors: Hüseyin GÜNGÖR, Ziya DUMLUPINAR, E-mail: hgungor78@hotmail.com, zdumlupinar@ksu.edu.tr Received: 24 February 2021 / Revised: 20 April 2021/ Accepted: 01 May 2021 / Online: 25 March 2022

\section{ABSTRACT}

To improve quantitative traits, it is essential to acknowledge genetic structure and diversity of the crop plants. In this study, 54 barley cultivars released from 1963 to date by different institutes in both Turkey and Bulgaria were screened with 18 iPBS and four SCoT markers to evaluate population structure and genetic diversity. According to the results, while total polymorphic band numbers was identified as 560, the polymorphic ones were found as 530 (438 and 92 amplified bands for iPBS and SCoT markers, respectively). In addition, the average polymorphic band number was found as 24.09. While the average polymorphism information content (PIC) value was 0.48 , the average PIC value was 0.48 for iPBS and 0.48 for SCoT markers. The highest PIC value was determined as 0.50 . The highest effective number of alleles, Shannon's information index, and Nei's genetic diversity were detected from the iPBS2271 marker at $1.61,0.52$ and 0.35 , respectively among the iPBS markers while the highest values were obtained from SCoT-71 marker as $1.55,0.32$ and 0.48 , respectively. As a result of a distribution of the 530 amplified bands in 54 barley cultivars, structure analysis showed that the subpopulations in the barley cultivars as a value of $\mathrm{k}=5$. The average expected heterozygosity and fixation indices were identified as 0.234 and 0.322 , respectively. Based on DICE similarity index, Mart1 and Zahir cultivars were found the most similar barley cultivars with $75 \%$ genetic similarity, whereas Özdemir and Karatay 94 and Tosunpaşa and Konevi cultivars were found 73\% similar. On the other hand, Bayrak and Avc1-2002 were found the most diverse cultivars with $19.9 \%$ genetic similarity. As a result, the barley cultivars released in Turkey and Bulgaria were found varying and, the genetic diversity and statistics index analysis indicated that iPBS and SCoT markers are powerful markers to perform genetic diversity analysis.

Keywords: Barley, Genetic diversity, iPBS-retrotransposons, SCoT marker, Structure analysis

(C) Ankara University, Faculty of Agriculture

\section{Introduction}

Plant genetic diversity (PGD) is the major component for plant's life and crop improvement. In addition, genetic diversity becomes more crucial in response to climatic change and different biotic and abiotic stresses in nature. Intra and inter-specific differences in plant genetic resources (PGR) are the basic requirement for all crop improvement programs as well as providing preferred traits for farmers. Genetic diversity is affected primarily by sexual recombination as well as evolutionary forces such as genetic drift, mutation, migration etc. and domestication or artificial selection (Bhandari et al. 2017). Barley (Hordeum vulgare), derived from its wild progenitor Hordeum vulgare ssp. spontaneum, is vital crop for the malting and brewing industries (about $20 \%$ of global production) and it constitutes as an important animal feed (about $75 \%$ of global production). It is also using as a staple food in different parts of the world $(5 \%)$ owing to adaptation to drought, soil salinity, and high altitudes (Baik \& Ullrich 2008; Blake et al. 2011). Barley is a diploid crop $(2 \mathrm{n}=14)$ with a genome size of 5.1 gigabases $(\mathrm{Gb})$ and its genome contains 26.159 'high-confidence' genes (The International Barley Genome Sequencing Consortium, 2012).

Molecular (DNA) markers can be used for analyses of molecular variations that resulted by deletion, duplication, inversion, and/or insertion in the genomes (Govindaraj et al. 2015). Start Codon Targeted polymorphism (SCoT) is a dominant marker system and has been effectively employed to detect genetic variations. Single 18-mer primers are used to anneal short conserved region neighboring the ATG translation initiation (or start) codon. This method provides high polymorphism and reproducible markers related with characters of biological interest (Collard \& Mackill 2009). SCoT marker system has been 
successfully applied in various crops such as Tunisian citrus species (Mahjbi et al. 2015), landrace chickpea (Pakseresht et al. 2013), durum wheat (Etminan et al. 2016), cultivars of Egyptian wheat (Abdel-Lateif \& Hewedy 2018), and 20 barley genotypes (Dora et al. 2017). Retrotransposons are repetitive and mobile sequences and observed in virtually all known eukaryotic genomes (Flavell et al. 1992). Particularly, retrotransposons are abundant in plant genomes and play important roles in genome evolution. In many cases, retrotransposons in plants cover more than $50 \%$ of the genome (Kumar \& Bennetzen 1999). Retrotransposons are classified into two groups like long terminal repeat (LTR) and non-LTR retrotransposons. The inter-primer binding site (iPBS) method is a PCR-based marker system as a reverse transcriptase primer-binding site (PBS) based on complement of tRNA in LTR retrotransposons (Kalendar et al. 2010).

Shannon's diversity index (I), and Nei's genetic diversity (h) were used to evaluate the information of the markers including iPBS and SCoT markers by the researches. Diversity of the statistics index values of the markers with a value of zero or below zero than couldn't be used in the analysis, because of lower level of knowledge for genetic diversity. The highest value of the diversity index tends to a greater level of polymorphism of the primers and, thus, assisted to select the best marker loci in the genetic separation analysis (Tahir et al. 2019).

The iPBS markers have been used in numerous crops including Turkish okra (Y1ldiz et al. 2015), common bean (Nemli et al. 2015), pea, lens (Baloch et al. 2015a \& 2015b, respectively) and tobacco (Yald1z et al. 2018). Thus, in the present study it was aimed to evaluate the genetic diversity of 37 Turkish and 17 Bulgarian barley genotypes using SCoT and iPBSretrotransposon markers for the first time.

\section{Material and Methods}

\subsection{Plant material}

The plant materials used in the study consisted of 54 barley cultivars developed by Aegean Agricultural Research Institute Turkey (AARI), Bahri Dağdaş International Agricultural Research Institute Turkey (BDIARI), Field Crops Central Research Institute Turkey (FCCRI), Trakya Agricultural Research Institute Turkey (TARI), Transition Zone Agricultural Research Institute Turkey (TZARI) and Institute of Agriculture Karnobat, Bulgaria (IAK). Cultivar name, origin, developing institute, spike type, release date and pedigree of the cultivars are given in Table 1.

\subsection{DNA isolation}

Genomic DNA of the barley cultivars was isolated from single seeds. Three seeds from each cultivar were planted in a $10.5 \mathrm{~cm}$ pot and at two leaves stage one seedling per pot left. The leaves were collected from the seedling and fixed in $2 \mathrm{ml}$ micro centrifuge tubes for DNA extraction. Genomic DNA of the cultivars was extracted using a cetyl trimethyl ammonium bromide method, indicated by Oliver et al. (2010). 
Table 1- Pedigree, origin and spike type of the barley genotypes used in the study

\begin{tabular}{|c|c|c|c|c|c|c|}
\hline No & Cultivar & Origin & Institute & $\begin{array}{l}\text { Spike } \\
\text { Type }\end{array}$ & $\begin{array}{l}\text { Release } \\
\text { Date }\end{array}$ & Pedigree \\
\hline 1 & Bozhin & Bulgaria & IAK & Six-Rowed & 1994 & $\mathrm{H} 280-7 / \mathrm{NaN}_{3}-$ mutant \\
\hline 2 & Zemela & Bulgaria & IAK & Six-Rowed & 2016 & F2 2012/01 x Кт 2152200 Gy - mutant \\
\hline 3 & Aheloy 2 & Bulgaria & IAK & Six-Rowed & 1994 & Hemus x №102/121 \\
\hline 4 & Zagoretz & Bulgaria & IAK & Two-Rowed & 2008 & $4943-41 \times 1023 K-7$ \\
\hline 5 & Alekssan & Bulgaria & IAK & Six-Rowed & 2017 & К-2169-01 х Кт 2145 \\
\hline 6 & Odisey & Bulgaria & IAK & Two-Rowed & 2011 & Obzor x Nutans 85242/64/ x Nutans 85242/64 (5) \\
\hline 7 & Bul Perun & Bulgaria & IAK & Two-Rowed & 1996 & Alpha x Jet \\
\hline 8 & Sladoran & Turkey & TARI & Two-Rowed & 1998 & Inrtoduced from Yugoslavia \\
\hline 9 & Kiral-97 & Turkey & BDIARI & Six-Rowed & 1997 & ADAIR/SL//WA1094-67 \\
\hline 10 & Erginel 90 & Turkey & TZARI & Six-Rowed & 1990 & Escourgeon Hop 2171 (Fransa) \\
\hline 11 & Tarm-92 & Turkey & FCCRI & Two-Rowed & 1992 & Tokak / local population no 4875 \\
\hline 12 & Çetin 2000 & Turkey & FCCRI & Six-Rowed & 2000 & Star (Iran) /line 4875 \\
\hline 13 & Tokak 157/37 & Turkey & FCCRI & Two-Rowed & 1963 & Selection from Landraces \\
\hline 14 & Avc1-2002 & Turkey & FCCRI & Six-Rowed & 2002 & Sci/3Gi-72AB58, F1//WA1245141 \\
\hline 15 & Burakbey & Turkey & FCCRI & Two-Rowed & 2013 & Coss/OWB 71080-44-1H//Obruk 86 \\
\hline 16 & Ayranc1 & Turkey & BDIARI & Two-Rowed & 2018 & Osk4.197/12-84//HB854/Astrix/3/Rod/4/Slad/3/Vict//Yrm/Lhfm \\
\hline 17 & Akhisar 98 & Turkey & AARI & Six-Rowed & 1998 & GEM*4/PİAST SEA-2636-4S-3S-2S-1S-0S \\
\hline 18 & Aydanhanım & Turkey & FCCRI & Two-Rowed & 2002 & GK Omega / Tarm 92 \\
\hline 19 & Çıldır 02 & Turkey & TZARI & Two-Rowed & 2002 & 3896/28//284/28/3/Cum-50/4/624/682/5/WBQT12 \\
\hline 20 & Hazar & Turkey & TARI & Six-Rowed & 2016 & Osk4.39/2-84//Barbe-Rousse \\
\hline 21 & Emon & Bulgaria & IAK & Two-Rowed & 1998 & 137HS-21/M-21-H/3/Malta/M-20-H/M-21-H/4/111G-65 \\
\hline 22 & Sancak & Turkey & AARI & Six-Rowed & 2014 & $\begin{array}{l}\text { 1861112/ROBUR/7/ HLLA/EH } \\
\text { 21B/6/MAN/HUIZ/M69.69/3/APAM/RL//H 272/4/CP/BRA/5/JOSO }\end{array}$ \\
\hline 23 & Egebeyi & Turkey & AARI & Six-Rowed & 2019 & $\begin{array}{l}\text { 2/Cm67/3/Market semple Marageh /5/ } \\
\text { ROHADES//TB//CHZO/3/GL/COPAL/3/BAR/RHODES//GL/COME }\end{array}$ \\
\hline 24 & Mart1 & Turkey & TARI & Six-Rowed & 2009 & Flam/WM/5/Yky387/3/Api/Cm67//Manc/4/Yrm/Lhfm \\
\hline 25 & Zahir & Bulgaria & IAK & Two-Rowed & 2016 & К $10 \times$ Кт 1206 \\
\hline 26 & Hasat & Turkey & TARI & Two-Rowed & 2014 & Rod/Scala \\
\hline 27 & Asparuh & Bulgaria & IAK & Two-Rowed & 2009 & 2119У-75 x Korten \\
\hline 28 & Deviniya & Bulgaria & IAK & Two-Rowed & 2011 & Tamara x Aster \\
\hline 29 & Vesletc & Bulgaria & IAK & Six-Rowed & 1994 & №102/121 x Karnobat \\
\hline 30 & Kuber & Bulgaria & IAK & Two-Rowed & 2009 & $2119 \mathrm{Y}-41 \times 2119 \mathrm{Y}-165$ \\
\hline 31 & Dariya & Bulgaria & IAK & Two-Rowed & 2016 & CRT 059 x Lambic \\
\hline 32 & Orfej & Bulgaria & IAK & Two-Rowed & 2007 & Kjfi x Nutans 8486/40 \\
\hline 33 & IZ Bori & Bulgaria & IAK & Six-Rowed & 2010 & K 280-7 NaN3 - mutant \\
\hline 34 & Konevi & Turkey & BDIARI & Two-Rowed & 1998 & CO55/OWB 710-80 (WBCB) \\
\hline 35 & Tosunpaşa & Turkey & FCCRI & Two-Rowed & 2016 & Atlas/Zarjou \\
\hline 36 & Zeynel Ağa & Turkey & FCCRI & Two-Rowed & 2003 & Antares/Ky63-1294//Lignee131 \\
\hline 37 & Yesevi 93 & Turkey & FCCRI & Two-Rowed & 1993 & Tokak / local population 4857 \\
\hline 38 & Bülbül 89 & Turkey & FCCRI & Two-Rowed & 1989 & 13GTH / local population \\
\hline 39 & IZ Sayra & Bulgaria & IAK & Two-Rowed & 2010 & Alfa x Nutans 85242/76/ x Yubileĭ 100 \\
\hline 40 & İnce-04 & Turkey & TZARI & Two-Rowed & 2004 & 4671/Tokak//4648/p12-119/3/WBCB-4 \\
\hline 41 & Bilgi-91 & Turkey & TZARI & Two-Rowed & 1991 & Selection \\
\hline 42 & Vamikhoca 98 & Turkey & AARI & Six-Rowed & 1998 & GEM*3/3/CR 115/POR//BLANCO MA \\
\hline 43 & Hilal & Turkey & AARI & Two-Rowed & 2010 & $\begin{array}{l}\text { Melusine/Aleli/3/Matico/Jet//Shyri/4/Canela/5/Arupo/K8755//Mora/3/Canela } \\
\text { CBSS 96M00698D-P-5M-1Y-1M-0Y }\end{array}$ \\
\hline 44 & Kalayc1-97 & Turkey & TZARI & Two-Rowed & 1997 & Erginel 90//364 TH / Tokak \\
\hline 45 & Orza 96 & Turkey & FCCRI & Two-Rowed & 1996 & Tokak $157-37 / 4857$ \\
\hline 46 & Bolayır & Turkey & TARI & Two-Rowed & 2007 & Osk 4.197/12-84//HB854/Astrix/3/Alpha/Durra \\
\hline 47 & Akar & Turkey & FCCRI & Two-Rowed & 2012 & Alpha/Durra//Antares/KY-63-1294/3/Tarm 92 \\
\hline 48 & Özdemir & Turkey & TZARI & Two-Rowed & 2005 & CUM/4060//P12-62/P169-2 \\
\hline 49 & Karatay 94 & Turkey & BDIARI & Two-Rowed & 1996 & VONTAGE/GÜZAK//TAPLANİ/3/REKAL/CUM50/RIGIC \\
\hline 50 & İmbat & Turkey & AARI & Six-Rowed & 2020 & 80.5064//BOLDO/MJA/3/GEM \\
\hline 51 & Larende & Turkey & BDIARI & Two-Rowed & 2006 & $\operatorname{ALM}(4652) /$ TOKAK//342TH/P12-119/3/W.BELT22 \\
\hline 52 & Ünver & Turkey & TZARI & Two-Rowed & 2013 & YEA389-3/YEA475-4//97-98DH8 \\
\hline 53 & Cumhuriyet 50 & Turkey & TZARI & Two-Rowed & 1973 & No:28 (Kayseri) / Mansholt's-2 Rijige (Holland) \\
\hline 54 & Bayrak & Turkey & AARI & Six-Rowed & 2014 & ARRAYAN/OLMO//LEO-B/3/Lignee527/Aths//Aths/Lignee686 \\
\hline
\end{tabular}

AARI: Aegean Agricultural Research Institute Turkey; BDIARI: Bahri Dağdaş International Agricultural Research Institute Turkey; FCCRI: Field Crops Central Research Institute Turkey; TARI: Trakya Agricultural Research Institute Turkey; TZARI: Transition Zone Agricultural Research Institute Turkey; IAK: Institute of Agriculture Karnobat, Bulgaria 


\section{3. iPBS and SCoT genotyping}

A set of iPBS (18) markers reported by Kalendar et al. (2010) and SCoT (4) markers by Collard et al. (2009) and Luo et al. (2010) were used for diversity analysis in this study.

The information about the markers is shown in Table 2.

Table 2- DNA primers used in molecular characterization of the barley genotypes

\begin{tabular}{|c|c|c|c|}
\hline Primer name & Primer sequence (5'-3') & $\operatorname{Tm}\left({ }^{\circ} \mathrm{C}\right)$ & G/C ratio \\
\hline iPBS 2075 & CTCATGATGCCA & 50 & 50 \\
\hline iPBS 2083 & CTTCTAGCGCCA & 50 & 58.3 \\
\hline iPBS 2095 & GCTCGGATACCA & 44.8 & 58.3 \\
\hline iPBS 2219 & GAACTTATGCCGATACCA & 50 & 44.4 \\
\hline iPBS 2222 & ACTTGGATGCCGATACCA & 55 & 55.6 \\
\hline iPBS 2230 & TCTAGGCGTCTGATACCA & 50 & 50 \\
\hline iPBS 2244 & GGAAGGCTCTGATTACCA & 53.3 & 50 \\
\hline iPBS 2255 & GCGTGTGCTCTCATACCA & 57.1 & 50 \\
\hline iPBS 2271 & GGCTCGGATGCCA & 57.4 & 69.2 \\
\hline iPBS 2276 & ACCTCTGATACCA & 50 & 46.2 \\
\hline iPBS 2375 & TCGCATCAACCA & 45.1 & 50 \\
\hline iPBS 2378 & GGTCCTCATCCA & 44.2 & 58.3 \\
\hline iPBS 2387 & GCGCAATACCCA & 50 & 58.3 \\
\hline iPBS 2388 & TTGGAAGACCCA & 43.4 & 50 \\
\hline iPBS 2391 & ATCTGTCAGCCA & 48 & 50 \\
\hline iPBS 2394 & GAGCCTAGGCCA & 51.3 & 66.7 \\
\hline iPBS 2400 & ССССТCСТTCTAGCGCCA & 57.4 & 66.7 \\
\hline iPBS 2415 & CATCGTAGGTGGGCGCCA & 50 & 66.7 \\
\hline SCoT-18 & ACCATGGCTACCACCGCC & 50 & 67 \\
\hline SCoT-39 & CAATGGCTACCACTAGCG & 50 & 56 \\
\hline SCoT-71 & CCATGGCTACCACCGCCG & 50 & 72 \\
\hline SCoT-74 & CCATGGCTACCACCGGCA & 50 & 67 \\
\hline
\end{tabular}

Polymorphism information content (PIC) values were calculated for each iPBS and SCoT markers using the formula described by Weir (1996) using a web based (https://www.gene-calc.pl/pic) software. PIC $=1-\sum \mathrm{P}_{\mathrm{i}}^{2}$, where $P_{i}$ is the frequency of the $i^{\text {th }}$ allele in the 54 barley cultivars in the research.

Polymerase chain reactions (PCR) for the iPBS and SCoT markers were completed in a total volume of $20 \mu \mathrm{L}$, including iPBS and SCoT markers $10 \mu \mathrm{L}$ primers $(1 \mu \mathrm{M}$ forward and reverse), $5 \mu \mathrm{L}(150 \mathrm{ng})$ of genomic DNA, $5 \mu \mathrm{L}$ of master mix $(0.1$ $\mu \mathrm{L} \mathrm{MgCl}, 0.2 \mu \mathrm{L}$ Taq polymerase enzyme, $2 \mu \mathrm{L}$ reaction buffer, $1.2 \mu \mathrm{L} d N T P$ mix $(\mathrm{A}+\mathrm{T}+\mathrm{G}+\mathrm{C})$ and $\left.1.5 \mu \mathrm{L} d d \mathrm{H}_{2} \mathrm{O}\right)$.

The reactions were conducted in Sensoquest Thermocycler (Labcycler) with a first denaturing $\left(94{ }^{\circ} \mathrm{C}, 5 \mathrm{~min}\right.$.), then 40 cycles of denaturing $\left(94{ }^{\circ} \mathrm{C}, 1 \mathrm{~min}\right)$, annealing $\left(44.2-57.4^{\circ} \mathrm{C}, 1 \mathrm{~min}\right.$, gradient) and extension $\left(72{ }^{\circ} \mathrm{C}, 1 \mathrm{~min}\right)$ afterwards a final extension $\left(72^{\circ} \mathrm{C}, 10 \mathrm{~min}\right)$. Products obtained from the PCR were fragmented by $3 \%$ agarose gel $\left[100 \mathrm{ml} 1 \mathrm{xTBE}\left\{1 \mathrm{Lt} \mathrm{H}_{2} \mathrm{O}+\right.\right.$ $10.8 \mathrm{~g}$ Tris +5.5 Boric acid $+0.5 \mathrm{M} 4 \mathrm{~mL}$ EDTA $(\mathrm{pH}: 8)\}$ with $3 \mathrm{~g}$ agarose] electrophoresis in $1 \mathrm{X}$ TBE buffer after adding $5 \mu \mathrm{L}$ loading dye to $10 \mu \mathrm{L}$ PCR product and running for approximately 2.5 hours at $120 \mathrm{~V}$ to $130 \mathrm{~V}$. The gels were stained with 1 $\mu 1 / \mathrm{mL}$ ethidium bromide. Gel images were captured using a Bio-Rad ChemiDoc (California, USA) gel documentation system and fragment sizes were determined by comparison with a 1 kb DNA ladder (Thermo Scientific Gene Ruler).

\subsection{Data analysis}

The presence or absence of iPBS and SCoT marker amplicons were scored as " 1 " or " 0 " to produce binary matrix data. The genetic similarity of the barley genotypes was calculated by Dice index (Dice 1945). A dendrogram was created based on an unweighted pair-group mean average (UPGMA) tree using NTSYSpc (Rohlf 1998) and effective allele numbers (ne), Nei's 
genetic diversity (Kimura \& Crow 1964) and Shannon's information index (Lewontin 1972) were calculated using POPGEN32 software (v3.2 Microsoft Windows-Based Freeware for Population Genetics Analysis) (Yeh et al. 2000).

A Bayesian model-based clustering algorithm named population structure was completed using STRUCTURE ver. 2.3.4 with almost default parameters to figure out the population structure of the barley cultivars. The admixture model (the ancestry and allele frequency model) which provides allele frequency correlations against a set of $\mathrm{K}$ genetics and shared allele frequencies were chosen to detect the populations numbers $(\mathrm{K})$ with the range of 1 to 10 , which are measured best in cases of complex population structure and the analysis repeated six times (Falush et al. 2003; Montilla-Bascon et al. 2013). The admixture alpha degree set to 1000 with 100000 Markov chain Monte Carlo (MCMC) and ten neutral simulations per K value were performed as indicated by Montilla-Bascon et al. (2013) and Earl \& vonHoldt (2012). The $\Delta \mathrm{K}$ method was implemented by STRUCTURE HARVESTER v0.6.94 web based software was used to determine K value that best fit the data (Evanno et al. 2005).

\section{Results and Discussion}

Molecular markers were used to determine genetic diversity and population structure for several plant species (Pasam et al. 2014; Dumlupinar et al. 2016; Güngör 2019; Hossein-Pour et al. 2019; Y1ldı et al. 2020). Kalendar et al. (2010) indicated that retrotransposon-based molecular markers may be efficiently used to locate developmental issues, at the intragenus or intraspecific scale, as for their addition into the genome results polymorphic DNA regions. Among the retrotransposan markers, iPBS markers are used universally due to ease of usage, high reproducibility and relatively inexpensive compared to other technologies and they do not require prior sequence knowledge (Y1ldiz et al. 2020). Among the PCR-based gene target technologies, SCoT markers reported as low in cost and effective to use besides, highly reproducibility and high polymorphic bands per reaction (Luo et al. 2010). Barley cultivars released from 1963 to date by different institutes in both Turkey and Bulgaria were evaluated for their genetic diversity and structural backgrounds. Total and polymorphic band numbers was identified as 560 and 530, respectively. Also, the average polymorphic band number was found as 24.09. The polymorphism ratios of the iPBS and SCoT markers was identified as 93.9\%and 97.8\%, respectively. In addition, the highest ne, h and I values were obtained from iPBS2271 marker (Table 3).

Table 3- PIC values and total polymorphic band numbers of DNA markers

\begin{tabular}{|c|c|c|c|c|c|c|c|c|}
\hline No & $\begin{array}{l}\text { Primer } \\
\text { Name }\end{array}$ & $\begin{array}{c}\text { Amplified } \\
\text { Band Number }\end{array}$ & $\begin{array}{l}\text { Polymorphic } \\
\text { Band Number }\end{array}$ & $\begin{array}{c}\text { Polymorphism } \\
\text { Rate (\%) }\end{array}$ & $\begin{array}{c}\text { PIC } \\
\text { Value }\end{array}$ & $\begin{array}{c}\text { Effective number of } \\
\text { alleles (ne) }\end{array}$ & $\begin{array}{c}\text { Nei's } \\
\text { genetic } \\
\text { diversity }(h)\end{array}$ & $\begin{array}{c}\text { Shannon's } \\
\text { information } \\
\text { index (I) }\end{array}$ \\
\hline 1 & iPBS 2075 & 24 & 23 & 95.83 & 0.49 & 1.51 & 0.29 & 0.44 \\
\hline 2 & iPBS 2083 & 23 & 23 & 100 & 0.49 & 1.48 & 0.31 & 0.48 \\
\hline 3 & iPBS 2095 & 15 & 15 & 100 & 0.40 & 1.51 & 0.29 & 0.44 \\
\hline 4 & iPBS 2219 & 20 & 18 & 90 & 0.47 & 1.46 & 0.28 & 0.43 \\
\hline 5 & iPBS 2222 & 29 & 27 & 93.1 & 0.50 & 1.42 & 0.26 & 0.40 \\
\hline 6 & iPBS 2230 & 23 & 18 & 78.26 & 0.49 & 0.95 & 0.12 & 0.21 \\
\hline 7 & iPBS 2244 & 27 & 27 & 100 & 0.50 & 1.37 & 0.25 & 0.41 \\
\hline 8 & iPBS 2255 & 26 & 26 & 100 & 0.50 & 1.48 & 0.28 & 0.43 \\
\hline 9 & iPBS 2271 & 28 & 28 & 100 & 0.50 & 1.61 & 0.35 & 0.52 \\
\hline 10 & iPBS 2276 & 33 & 33 & 100 & 0.48 & 1.57 & 0.32 & 0.48 \\
\hline 11 & iPBS 2375 & 22 & 20 & 90.9 & 0.48 & 1.34 & 0.22 & 0.35 \\
\hline 12 & iPBS 2378 & 26 & 20 & 76.92 & 0.50 & 1.33 & 0.20 & 0.31 \\
\hline 13 & iPBS 2387 & 26 & 26 & 100 & 0.50 & 1.54 & 0.31 & 0.48 \\
\hline 14 & iPBS 2388 & 22 & 21 & 95.45 & 0.48 & 1.27 & 0.22 & 0.36 \\
\hline 15 & iPBS 2391 & 22 & 20 & 90.9 & 0.48 & 1.29 & 0.21 & 0.34 \\
\hline 16 & iPBS 2394 & 25 & 23 & 92 & 0.50 & 1.45 & 0.29 & 0.44 \\
\hline 17 & iPBS 2400 & 39 & 34 & 87.17 & 0.40 & 1.38 & 0.26 & 0.40 \\
\hline 18 & iPBS 2415 & 36 & 36 & 100 & 0.44 & 1.39 & 0.25 & 0.39 \\
\hline 19 & SCoT-18 & 20 & 20 & 100 & 0.47 & 1.50 & 0.30 & 0.46 \\
\hline 20 & SCoT-39 & 30 & 30 & 100 & 0.49 & 1.54 & 0.31 & 0.47 \\
\hline 21 & SCoT-71 & 24 & 22 & 91.66 & 0.49 & 1.55 & 0.32 & 0.48 \\
\hline 22 & SCoT-74 & 20 & 20 & 100 & 0.47 & 1.53 & 0.31 & 0.47 \\
\hline \multicolumn{2}{|r|}{ Average } & 25.45 & 24.09 & 94.65 & 0.48 & 1.43 & 0.27 & 0.42 \\
\hline \multicolumn{2}{|r|}{ Total } & 560 & 530 & - & - & & & \\
\hline
\end{tabular}


Five hundred thirty polymorphic bands obtained from by iPBS (438 bands) and SCoT (92 bands) markers were used to create a dendrogram (Figure 1) and also used to calculate effective allele numbers (ne), Nei's genetic diversity and Shannon's information index for DNA markers (Table 3) and cultivars used in the study (Table 4). In current study, SCoT and iPBS markers confirmed useful in determination genetic diversity and population structure of barley cultivars. A ratio of $94.6 \%$ polymorphism was obtained from both SCoT and iPBS markers and the polymorphic band number was found as 24.09 . In a recent study, Yildiz et al. (2020) reported $92 \%$ of polymorphic bands and 8.6 bands per iPBS marker reaction as 20 iPBS markers used and 158 polymorphic bands were generated and Hossein-Pour et al. (2019) stated 3.16 average band number per primer in iPBS markers. On the other hand, Luo et al. (2010) indicated 8.27 bands per SCoT primer and 76.19\% polymorphism rate with 208 total polymorphic bands and Khodayari et al. (2012) reported 8.1 allele per locus in an Iranian barley landrace panel. Pasam et al. (2014) indicated a 5.74 average allele number in SSR markers in a spring barley set, while Elakhdar et al. (2018) indicated four allele number/locus in barley for SSR and SNP markers.

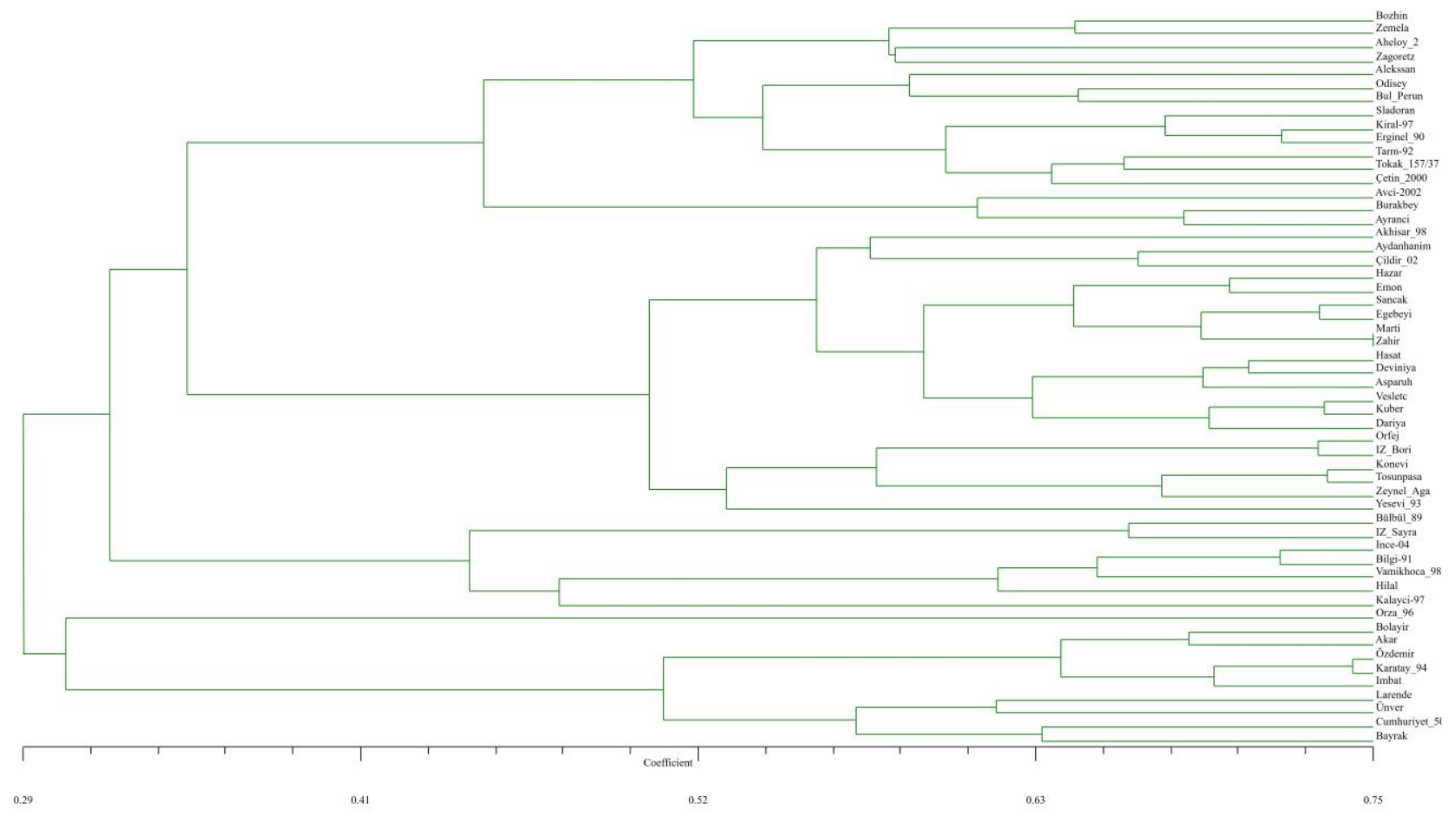

Figure 1- Dendrogram of 54 barley genotypes based on data of iPBS and SCoT markers according to UPGMA method with the Dice similarity index 
Table 4- Summary statistics for 54 Barley genotypes assessed with DNA primers used in molecular characterization

\begin{tabular}{|c|c|c|c|c|}
\hline No & Genotypes & $\begin{array}{l}\text { Effective number } \\
\text { of alleles }\left(n e^{*}\right)\end{array}$ & $\begin{array}{l}\text { Nei's genetic } \\
\text { diversity }\left(h^{*}\right)\end{array}$ & $\begin{array}{c}\text { Shannon's information } \\
\text { index }\left(I^{*}\right)\end{array}$ \\
\hline 1 & Bozhin & 1.50 & 0.33 & 0.52 \\
\hline 2 & Zemela & 1.55 & 0.35 & 0.54 \\
\hline 3 & Aheloy 2 & 1.43 & 0.30 & 0.47 \\
\hline 4 & Zagoretz & 1.57 & 0.36 & 0.55 \\
\hline 5 & Alekssan & 1.50 & 0.33 & 0.51 \\
\hline 6 & Odisey & 1.44 & 0.30 & 0.48 \\
\hline 7 & Bul Perun & 1.55 & 0.35 & 0.54 \\
\hline 8 & Sladoran & 1.63 & 0.38 & 0.57 \\
\hline 9 & Kiral-97 & 1.65 & 0.39 & 0.58 \\
\hline 10 & Erginel 90 & 1.65 & 0.39 & 0.58 \\
\hline 11 & Tarm-92 & 1.59 & 0.37 & 0.55 \\
\hline 12 & Çetin 2000 & 1.57 & 0.36 & 0.55 \\
\hline 13 & Tokak 157/3 & 1.62 & 0.38 & 0.57 \\
\hline 14 & Avc1-2002 & 1.62 & 0.38 & 0.57 \\
\hline 15 & Burakbey & 1.57 & 0.36 & 0.55 \\
\hline 16 & Ayranc1 & 1.59 & 0.37 & 0.55 \\
\hline 17 & Akhisar 98 & 1.59 & 0.37 & 0.55 \\
\hline 18 & Aydanhanım & 1.53 & 0.34 & 0.53 \\
\hline 19 & Çıldır 02 & 1.56 & 0.36 & 0.54 \\
\hline 20 & Hazar & 1.59 & 0.37 & 0.55 \\
\hline 21 & Emon & 1.61 & 0.38 & 0.56 \\
\hline 22 & Sancak & 1.67 & 0.40 & 0.59 \\
\hline 23 & Egebeyi & 1.55 & 0.35 & 0.54 \\
\hline 24 & Mart1 & 1.61 & 0.38 & 0.56 \\
\hline 25 & Zahir & 1.55 & 0.35 & 0.54 \\
\hline 26 & Hasat & 1.62 & 0.38 & 0.57 \\
\hline 27 & Asparuh & 1.57 & 0.36 & 0.55 \\
\hline 28 & Deviniya & 1.61 & 0.38 & 0.57 \\
\hline 29 & Vesletc & 1.55 & 0.35 & 0.54 \\
\hline 30 & Kuber & 1.61 & 0.38 & 0.56 \\
\hline 31 & Dariya & 1.49 & 0.33 & 0.51 \\
\hline 32 & Orfej & 1.56 & 0.36 & 0.54 \\
\hline 33 & IZ Bori & 1.57 & 0.36 & 0.55 \\
\hline 34 & Konevi & 1.56 & 0.36 & 0.54 \\
\hline 35 & Tosunpaşa & 1.55 & 0.35 & 0.54 \\
\hline 36 & Zeynel Ağa & 1.53 & 0.34 & 0.53 \\
\hline 37 & Yesevi 93 & 1.50 & 0.33 & 0.51 \\
\hline 38 & Bülbül 89 & 1.46 & 0.31 & 0.49 \\
\hline 39 & IZ Sayra & 1.48 & 0.32 & 0.50 \\
\hline 40 & İnce-04 & 1.48 & 0.32 & 0.50 \\
\hline 41 & Bilgi-91 & 1.52 & 0.34 & 0.52 \\
\hline 42 & Vamikhoca $S$ & 1.42 & 0.30 & 0.47 \\
\hline 43 & Hilal & 1.48 & 0.32 & 0.50 \\
\hline 44 & Kalayc1-97 & 1.49 & 0.33 & 0.51 \\
\hline 45 & Orza 96 & 1.64 & 0.39 & 0.58 \\
\hline 46 & Bolayır & 1.60 & 0.37 & 0.56 \\
\hline 47 & Akar & 1.56 & 0.36 & 0.54 \\
\hline 48 & Özdemir & 1.58 & 0.36 & 0.55 \\
\hline 49 & Karatay 94 & 1.52 & 0.34 & 0.52 \\
\hline 50 & İmbat & 1.46 & 0.31 & 0.49 \\
\hline 51 & Larende & 1.50 & 0.33 & 0.52 \\
\hline 52 & Ünver & 1.49 & 0.33 & 0.51 \\
\hline 53 & Cumhuriyet! & 1.40 & 0.28 & 0.46 \\
\hline 54 & Bayrak & 1.34 & 0.25 & 0.42 \\
\hline \multicolumn{2}{|c|}{ Average } & 1.54 & 0.35 & 0.53 \\
\hline
\end{tabular}

PIC values were also calculated for each DNA markers and shown in Table 3. The average PIC value was 0.48 and the highest PIC value was 0.50 , while the lowest one was 0.40 . The highest ne, h, and I were obtained from the iPBS2271 marker at $1.61,0.35$ and 0.52 , respectively, in contrast the lowest ones were found in the iPBS2230 marker at $0.95,0.12$ and 0.21 , respectively. In addition, the total average ne, h, and I values were found as $1.43,0.27$ and 0.42 , respectively (Table 3). A brief statistical results for each of the 54 barley genotypes was presented in Table 4 . The highest ne, h, and I were obtained from Sancak cultivar at 1.67, 0.40 and 0.59, respectively, though the lowest values were observed in the Bayrak cultivar at 1.34, 0.25 and 0.42 , respectively. In addition, the total average ne, h, and I were identified as $1.54,0.35$ and 0.53 , respectively. Polymorphism information content is a measure of the primers used in a set of genotypes. In current study, the average PIC 
value was 0.48 and PIC values of the iPBS markers ranked from 0.40 to 0.50 obtained from iPBS markers, while 0.46 to 0.49 for the SCoT markers. In earlier studies, Moragues et al. (2007) indicated an average PIC value 0.24 for AFLP and 0.70 for SSR markers in a durum wheat panel. Khodayari et al. (2012) determined a PIC value of 0.65 for SSR markers in barley landraces. Pasam et al. (2014) stated a 0.54 average PIC value for SSR markers in spring barley. Elakhdar et al. (2018) also reported a PIC value of 0.49 in barley genotypes. Hossein-Pour et al. (2019) reported an average PIC value with 0.20. Güngör (2019) reported an average PIC value of 0.72 on durum wheat cultivars. In addition, Kiraz et al. (2019) determined a PIC value of 0.79 in bread wheat mutant lines. Aydemir et al. (2020) calculated an average PIC value as 0.98 in a durum wheat population for DNA markers.

Based on a distribution of the 530 bands in 54 barley cultivars, STRUCTURE analysis was conducted with K=10. The subpopulations in the barley cultivars supported a value of $k=5$ (Figure 2) and the amount of admixture of each cultivar in the related subpopulation detected five barley subpopulations by STRUCTURE analysis is shown in Figure 3. According to STRUCTURE data, sub-population A, B, C, D and E indicated an admixture with 16.6\%, 38.8\%, 24\%, $12.9 \%$ and $7.7 \%$ of the genotypes, respectively (Figure 3). Despite the maximum $\Delta K$ value was conducted at $K=10$, clusters at $K=5$ were best identified in terms of genotypic data. The sub-populations of the barley cultivars were grouped regardless to country, spike type and pedigree. In earlier works in different barley accessions the genetic diversity and population structure described two (Elakhdar et al. 2016), three (Elakhdar et al. 2018), five (Munoz- Amatriain et al. 2014), seven (Pandey et al. 2006), eight (Zhang et al. 2014) and 10 (Pasam et al. 2014) subpopulations.

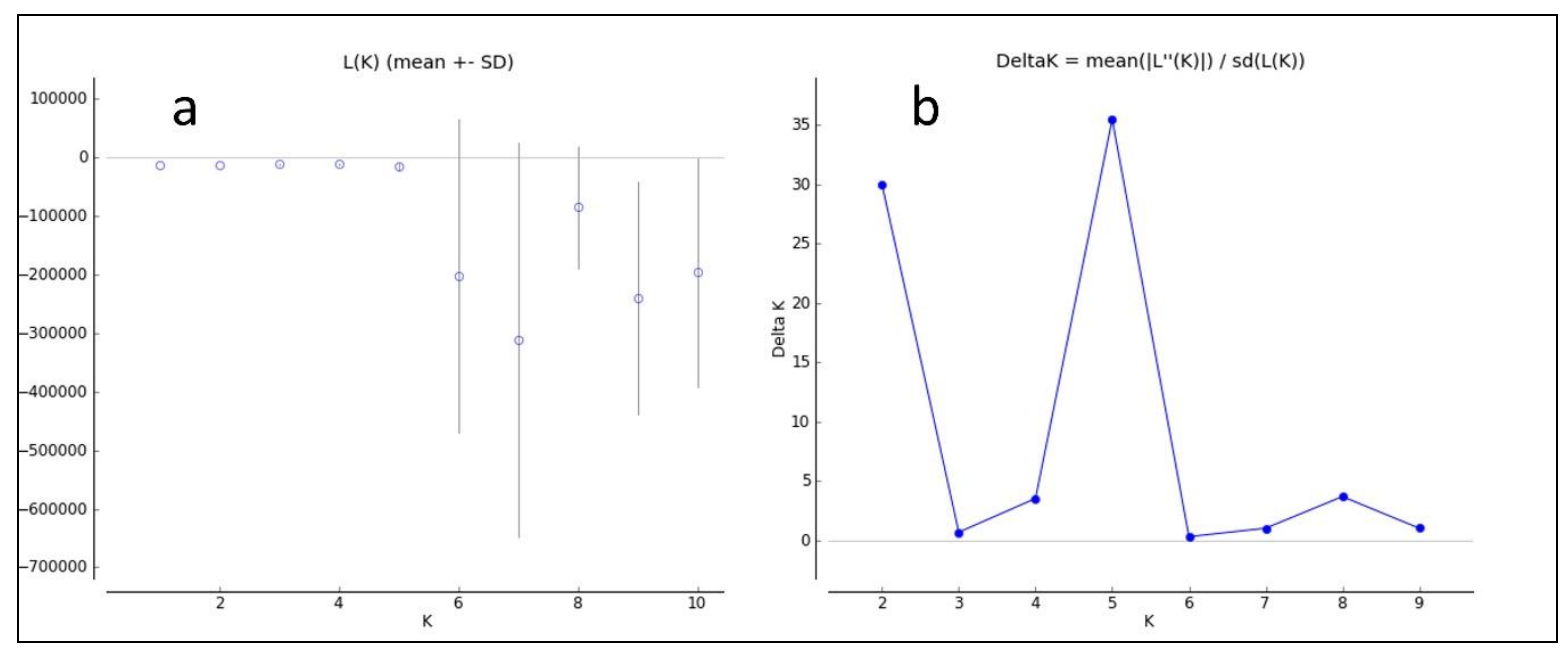

Figure 2- Admixture model of structure of $\operatorname{Ln} P(D)$ and $\Delta K$ for Barley subpopulations. a; Mean value of the statistic $L n P$ (D) b; DK

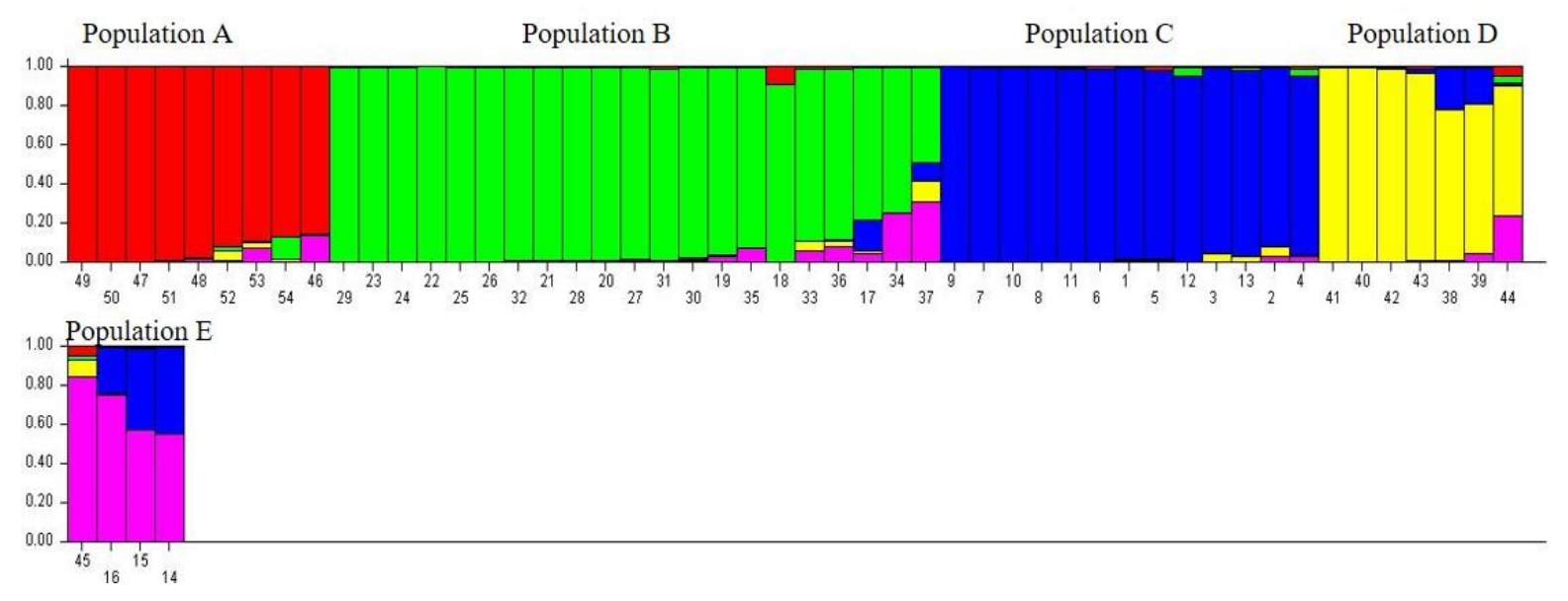

Figure 3- Population structure analysis of barley genotypes

To acknowledge about the genetic population structure of cultivars derived from different pedigrees. A Bayesian clustering modelling conducted in STRUCTURE software using 560 DNA markers. The number of groups (K) was arranged against $\Delta \mathrm{K}$ to examine the most appropriate value of $\mathrm{K}$. The highest $\Delta \mathrm{K}$ value was detected at $\mathrm{K}=5(\Delta \mathrm{K}=35.4787)$, including five subpopulations. At this K, most of the genotypes were linked to population B (Figure 1). 
Expected heterozygosity (He) and fixation indices (Fst) values of sub-populations are shown in Table 5 and genetic differentiation measurement based on Fst values among sub-populations are indicated in Table 6. The barley sub-populations varied for Fst, determined to observe the relation within alleles drawn at varying scales of a hierarchically sub-divided population, however it was primarily modeled to measure the quantity of allelic fixation due to genetic alteration. The average He and Fst were found as 0.2335 and 0.3216, respectively (Table 5). The highest He was calculated from sub-population E with 0.3435 , while the highest Fst value was obtained from sub-population A with 0.4697 . Genetic differentiation based on Fst values among five barley sub-populations, sub-population A and B was found the most diverse populations with a value of 0.1225 (Table 6). The highest ne shows the existence of a high genetic variation suggesting the alleles capable to proceed in next-generation (Kimura 1965; Romero et al. 2019). It is concluded that ne is an important measure to assess markers with a high addition to variations in germplasms. In current study, the average ne was found 1.42 which was higher than a recent study reported as 1.26 by Barut et al. (2020) similar with a study for iPBS markers (Hossein-Pour et al. 2019). Shannon's information index is an important model to evaluate the diversity in a given set as it distinguishes the genetic variation in a germplasm combining plenty and equality (Y1ldiz et al. 2020). Shannon's information index and Nei's genetic diversity brought out the presence of satisfactory amount of genetic diversity in current germplasm. The average Shannon's information index was 0.42 , which was consistent with previous works using different molecular markers (Barut et al. 2020). The average gene diversity was found 0.27 using SCoT and iPBS marker technologies in consistent with Hossein-Pour et al. (2019). In the study the average ne, h, and I of the cultivars were also calculated to evaluate cultivars with high ne, $h$ and I. The average ne was 1.54 , h was 0.35 and I was 0.53 (Table 4). Karagöz et al. (2020) reported the ne, I and h values for Oregano by iPBS marker respectively as 1.61, 0.37 and 0.55 . Hossein-Pour et al. (2019) reported that ne, h and I values for quinoa by iPBS marker respectively as $1.52,0.32$ and 0.49 . The expected heterozygosity values indicate the diversity amount of the primers, as those values are high; the primers variability is high (Pompanon et al. 2005). In previous works, He was reported as 0.28 in a barley set (Elakhdar et al. 2018) which was similar with our results, while (Zhang et al. 2014) indicated a value of 0.52 for a 80 wild and 16 commercial Tibetan barley genotypes. Elakhdar et al. (2018) explain the differences in expected heterozygosity as primer problems such as deletion of alleles and occurrence of inadequate alleles at annealing spots. Nevertheless, it is also concluded that heterozygote deficiencies might be due to Technical limitations (Elakhdar et al. 2018), while cleistogamy in barley may reduce the heterozygosity that flower sheds its pollen before opening makes it almost completely autogamous (Wang et al. 2013). In the research, the average Fst was 0.32. Elakhdar et al. (2018) reported an Fst value of 0.57 in an Egyptian barley set using SSR and SNP markers and stated that the difference between populations was higher than variation among population, which was in harmony with our findings.

Table 5- Heterozygosity and Fst values of 5 barley sub-populations

\begin{tabular}{ccc}
\hline Sub-population $(\mathrm{K})$ & Expected heterozygosity $(\mathrm{He})$ & $F_{S T}$ \\
\hline A & 0.1903 & 0.4697 \\
B & 0.2085 & 0.3560 \\
C & 0.2224 & 0.3294 \\
D & 0.2030 & 0.4429 \\
E & 0.3435 & 0.0098 \\
Average & 0.2335 & 0.3216 \\
\hline
\end{tabular}

Table 6- Genetic differentiation based on Fst values among five Barley sub-populations identified by population structure analysis

\begin{tabular}{ccccc}
\hline Sub-populations $(K)$ & Sub-Pop A & Sub-Pop B & Sub-Pop C & Sub-Pop D \\
\hline Sub-Pop A & - & & & \\
Sub-Pop B & 0.1225 & - & & \\
Sub-Pop C & 0.1067 & 0.0981 & - & - \\
Sub-Pop D & 0.1109 & 0.1033 & 0.0886 & 0.0459 \\
Sub-Pop E & 0.0582 & 0.0456 & 0.0371 & \\
\hline
\end{tabular}

The dendrogram generated by UPGMA clustered into two groups. The first group was consisted of 10 cultivars and the second one which was the major one included 44 cultivars. The first small group consisted of two sub-groups with 9 members in the first and one cultivar in the second one. The major group firstly divided into two and the first group contained 7 cultivars, the second sub-group clustered in two groups with 20 and 16 cultivars in each group, respectively. Martı and Zahir cultivars were found the most similar barley cultivars with $75 \%$ genetic similarity, whereas Özdemir and Karatay 94 and Tosunpaşa and Konevi cultivars were found 73\% similar. On the other hand, Bayrak and Avc1-2002 were found the most diverse cultivars with $19.9 \%$ genetic similarity. Genetic diversity studies with 530 polymorphic bands obtained from four SCoT and 18 iPBS markers recommended that the commercial barley cultivars had high genetic variation due to different sources. The existence of genetic variation in a population may be described originated from the amount of various alleles, their position, the impacts they have on accomplishment and the complete characteristics of observable phenotypes of desired the ones that construct the population (Hamrick et al. 1992). Expanding the genetic base is one of the main goals of the breeders while cultivation is mostly done by genetically uniform cultivars thus raising the concerns about narrowing the genetic base. A dendrogram was created using genotypic data obtained from iPBS and SCoT markers. A wide genetic diversity 
was observed on the commercial barley cultivars derived from different institutes of Turkey and Bulgaria. The genetic diversity of the barley cultivars ranked from $19.9 \%$ to $75 \%$. As it is shown in Figure 1, the barley cultivars obtained from IAK were mostly grouped together (Bozhin, Zemela, Aheloy 2, Zagoretz, Alekssan, Odisey, Bul Perun) with the exceptions. Although the most similar cultivars Martı and Zahir derived from different institutes (TARI and IAK, respectively), they are neighbors and the most closest institutes geographically. Bayrak and Avc1-2002 were the most diverse cultivars obtained from AARI and FCCRI, even they are both six-rowed. Besides their different origination, the high dissimilarity might be caused by their growth habit since Bayrak is a spring barley, while Avc1-2002 is a winter type. In earlier studies, genetic diversity of the barley accessions was revealed using different molecular marker technologies. Orabi et al. (2009) indicated a high genetic diversity in wild barley accessions and barley landraces was nearly high as well. Khodayari et al. (2012) stated a genetic diversity in Iranian barley landraces and defined Iranian gene pool as a valuable source of new alleles for crop improvement. Pasam et al. (2014) indicated a genetic diversity in a wide barley accession including both two and six-rowed barleys. Bengtsson et al. (2017) reported a higher genetic diversity in two-rowed (SSR: 0.431; SNP: 0.305) barley lines compared to six-rowed ones (SSR: 0.386; SNP: 0.225). Our findings are in confidence with the previous works.

\section{Conclusions}

In the current study, 54 barley cultivars were characterized by 18 iPBS and four SCoT markers and 530 polymorphic bands were produced. Population structure analysis conducted with genotypic data revealed five subpopulations in the barley cultivars. Diversity analysis showed that cultivars clustered with regardless to the releasing institutes and country origins. However, Martı and Zahir cultivars originated from Trace region with different country origins were found the most similar barley cultivars with 75\% genetic similarity. Nevertheless, Bayrak and Avc1-2002 were found the most diverse cultivars with $19.9 \%$ genetic similarity. The average effective number of alleles, Shannon's information index, and Nei's genetic diversity were found 1.43, 0.27 and 0.42 , respectively. Structure analysis of barley cultivars derived from different pedigrees resulted in five sub-populations. In addition, the average expected He and Fst values were determined as 0.234 and 0.322 , respectively. These results showed that the iPBS and SCoT markers are polymorphic, may be used for diversity analysis of barley.

\section{Acknowledgements}

This study was supported by the Scientific Research Council of Duzce University (DU BAP Project No: 2018.11.04.735).

\section{References}

Abdel-Lateif K S \& Hewedy O A (2018). Genetic diversity among Egyptian wheat cultivars using SCoT and ISSR markers. SABRAO Journal of Breeding and Genetics 50: 36-45

Aydemir G, Dumlupinar Z, Yüce I, Baskonus T, Sunulu S \& Gungor H (2020). Evaluation of individuals obtained from B28 $\times$ Kunduru-1149 reciprocal cross population by functional markers. KSU J. Agric Nat 23(4): 1005-1011

Baik B-K \& Ullrich S E (2008) Barley for food: characteristics, improvement, and renewed interest. Journal of Cereal Science 48(2): 233242

Baloch F S, Alsaleh A, Sáenz de Miera L E, Hatipoğlu R, Çiftçi V, Karaköy T, Yıldız M \& Özkan H (2015a). DNA based iPBSretrotransposon markers for investigating the population structure of pea (Pisum sativum) germplasm from Turkey. Biochemical Systematics Ecology 61: 244-252

Baloch F S, Derya M, Andeden E E, Alsaleh A, Comertpay G, Kilian B \& Ozkan H (2015b). Inter primer binding site (iPBS) retrotransposon and ISSR diversity among wild lens species. Biochemical Systematics Ecology 58: 162-168

Barut M, Nadeem M A, Karakoy T \& Baloch F S (2020). DNA fingerprinting and genetic diversity analysis of world quinoa germplasm using iPBS-retrotransposon marker system. Turkish Journal of Agriculture and Forestry 44(5): 479-491

Bengtsson T, PPP Barley Consortium, Manninen O, Jahoor A \& Orabi J (2017). Genetic diversity, population structure and linkage disequilibrium in Nordic spring barley (Hordeum vulgare L. subsp. vulgare). Genetic Resources and Crop Evolution 64(8): 2021-2033. doi: 10.1007/s10722-017-0493-5.

Bhandari H R, Bhanu A N, Srivastava K, Singh M N, Shreya \& Hemantaranjan A (2017). Assessment of genetic diversity in crop plants - an overview. Advances Plants \& Agriculture Research 7(3): 279-286. doi:10.15406/apar.2017.07.00255.

Blake T, Blake V, Bowman J \& Abdel-Haleem H (2011). In Barley: Production, Improvement and Uses (ed. S. E. Ullrich) $522-531$ (WileyBlackwell)

Collard B C Y \& Mackill D J (2009). Start codon targeted (SCoT) polymorphism: a simple, novel DNA marker technique for generating gene-targeted markers in plants. Plant Molecular Biology Reporter 27(1): 86-93

Dice L R (1945). Measures of the amount of ecologic association between species. Ecology 26: 297-302

Dora S A, Mansour M, Aboulila A A \& Abdelwahab E (2017). Genetic diversity and relationships among some barley genotypes for Net Blotch Disease Resistance using RAPD, SCoT and SSR Markers. Egyptian Journal of Genetics and Cytology 46(1): 139-165. doi: 10.21608/EJGC.2018.9510

Dumlupinar Z., Jellen E N, Bonman J M \& Jackson E W (2016). Genetic diversity and crown rust resistance of oat landracesfrom various locations throughout Turkey. Turkish Journal of Agriculture and Forestry 40(2): 262-268

Earl D A \& vonHoldt B M (2012). STRUCTURE HARVESTER: a website and program for visualizing STRUCTURE output and implementing the Evanno method. Conservation Genetics Resources 4(2): 359-361

Elakhdar A, Abdelsattar M, Amer K, Assma R \& Kumamaru T (2016). Population structure and marker-trait association of salt tolerance in barley (Hordeum vulgare L.). Comptes Rendus Biologies 339(11-12): 454-461 
Elakhdar A, Kumamaru T, Qualset C O, Brueggeman R S, Amer K \& Capo-chichi L (2018). Assessment of genetic diversity in Egyptian barley (Hordeum vulgare L.) genotypes using SSR and SNP markers. Genetic Resources and Crop Evolution 65(7): 1937-1951. doi: 10.1007/s10722-018-0666-x

Etminan A, Pour-Aboughadareh A, Mohammadi R, Ahmadi-Rad A, Noori A, Mahdavian Z \& Moradi Z (2016). Applicability of start codon targeted (SCoT) and inter-simple sequence repeat (ISSR) markers for genetic diversity analysis in durum wheat genotypes. Biotechnology \& Biotechnological Equipment 30(6): 1075-1081. doi: 10.1080/13102818.2016.1228478

Evanno G, Regnaut S \& Goudet J (2005). Detecting the number of clusters of individuals using the software STRUCTURE: A simulation study. Molecular Ecology 14(8): 2611-2620. doi: 10.1111/j.1365-294X.2005.02553.x

Falush D, Stephens M \& Pritchard J K (2003). Inference of population structure using multilocus genotype data: linked loci and correlated allele frequencies. Genetics 164(4): 1567-1587

Flavell A J, Dunbar E, Anderson R, Pearce SR, Hartley R \& Kumar A (1992). Ty1-copia group retrotransposons are ubiquitous and heterogeneous in higher plants. Nucleic Acids Research 20(14): 3639-3644. Doi: 10.1093/nar/20.14.3639

Govindaraj M, Vetriventhan M \& Srinivasan M (2015) Importance of genetic diversity assessment in crop plants and its recent advances: an overview of its analytical perspectives. Genetics Research International 2015: 1-14

Güngör H (2019). Allelic variations and agronomic comparisons of durum wheat cultivars under East-Mediterranean conditions. International Journal of Agriculture and Biology 21(4): 891-898. Doi: 10.17957/IJAB/15.0972

Hamrick J L, Godt M J W \& Sherman-Broyles S L (1992). Factors influencing levels of genetic diversity in woody plant species. New Forests 6: 95-124

Hossein-Pour A, Haliloglu K, Ozkan G \& Tan M (2019). Genetic diversity and population structure of Quinoa (CHENOPODIUM QUINOA Willd.) using iPBS-retrotransposons markers. Applied Ecology and Environmental Research 17(2): 1899-1911. Doi: 10.15666/aeer/1702_18991911

Kalendar R, Antonius K, Smýkal P \& Schulman A H (2010). iPBS: a universal method for DNA fingerprinting and retrotransposon isolation. Theoretical and Applied Genetics 121(8): 1419-1430. doi:10.1007/s00122-010-1398-2

Karagöz H, Cakmakci R, Hosseinpour A, Ozkan G \& Haliloglu K (2020). Analysis of genetic variation and population structure among of oregano (Origanum acutidens L.) accessions revealed by agro-morphological traits, oil constituents and retrotransposon-based interprimer binding sites (iPBS) markers. Genetic Resources and Crop Evolution 67: 1367-1384

Khodayari H, Saeidi H, Roofigar A A, Rahiminejad M R, Pourkheirandish M \& Komatsuda T (2012). Genetic diversity of cultivated barley landraces in Iran measured using microsatellites. International Journal of Bioscience, Biochemistry and Bioinformatics 2(4): 287-290. doi: 10.7763/IJBBB.2012.V2.118

Kimura M (1965). A stochastic model concerning the maintenance of genetic variability in quantitative characters. Proceedings of the National Academy of Sciences of the United States of America 54(3): 731-736. doi:10.1073/pnas.54.3.731

Kimura M \& Crow J F (1964). The number of alleles that can be maintained in a finite population. Genetics 49: 725-738

Kiraz H, Yüce İ, Kaya E, Kekilli Ö, Ocaktan H, Topsakal M, Gürocak N Y, Osanmaz H, Kılınç F M, Başkonuş T \& Dumlupinar Z (2019). Characterization of M3 mutants of Seri 82 bread wheat cultivar using functional markers. Black Sea Journal of Agriculture 2(4): 194-202

Kumar A \& Bennetzen J L (1999). Plant retrotransposons. Annu Rev Genet 33: 479-532

Lewontin R C (1972). Testing the theory of natural selection. Nature 236:181-182

Luo C, He X-H, Chen H, Ou S-J \& Gao M-P (2010). Analysis of diversity and relationships among cultivars using start codon targeted (SCoT) markers. Biochemical Systematics and Ecology 38: 1176-1184

Mahjbi A, Baraket G, Oueslati A \& Salhi-Hannachi A (2015). Start Codon Targeted (SCoT) markers provide new insights into the genetic diversity analysis and characterization of Tunisian Citrus species. Biochemical Systematics and Ecology 61: 390-398

Moragues M, Moralejo M, Sorrells M E \& Royo C (2007). Dispersal of durum wheat [Triticum turgidum L. Ssp. turgidum Convar. Durum (Desf.) MacKey] landraces across The Mediterranean basin assessed by AFLPs and Microsatellites. Genetic Resources and Crop Evolution 54: 1133-1144

Montilla-Bascon G, Sanchez-Martin J, Rispail N, Rubiales D, Mur L, Langdon T, Griffiths I, Howarth C \& Parts E (2013). Genetic diversity and population structure among oat cultivars and landraces. Plant Molecular Biology Reporter 31: 1305-1314. Doi:10.1007/s11105-0130598-8

Munoz-Amatriain M, Cuesta-Marcos A, Endelman J B, Comadran J, Bonman J M, Bockelman H E, Chao S, Russell J, Waugh R, Hayes P M \& Muehlbauer G J (2014). The USDA barley core collection: genetic diversity, population structure, and potential for genome-wide association studies. PLoS ONE 9:e94688. https://doi.org/10.1371/journal.pone.0094688

Nemli S, Kianoosh T \& Tanyolaç M B (2015). Genetic diversity and population structure of common bean (Phaseolus vulgaris L.) accessions through retrotransposon-based interprimer binding sites (iPBSs) markers. Turkish Journal of Agriculture and Forestry 39: 940-948

Oliver R E, Obert D E, Hu G, Bonman J M, O’Leary-Jepsen E \& Jackson E W (2010). Development of oat-based markers from barley and wheat microsatellites. Genome 53(6): 458-471

Orabi J, Jahoor A\& Backes G (2009). Genetic diversity and population structure of wild and cultivated barley from West Asia and North Africa. Plant Breeding 128(6): 606-614

Pakseresht F, Talebi R \& Karami E (2013). Comparative assessment of ISSR, DAMD and SCoT markers for evaluation of genetic diversity and conservation of landrace chickpea (Cicer arietinum L.) genotypes collected from north-west of Iran. Physiology and Molecular Biology of Plants 19: 563-574

Pandey M, Wagner C, Friedt W \& Ordon F (2006) Genetic relatedness and population differentiation of Himalayan hulless barley (Hordeum vulgare L.) landraces inferred with SSRs. Theoretical and Applied Genetics 113:715-729

Pasam R K, Sharma R, Walther A, Özkan H, Graner A \& Kilian B (2014). Genetic diversity and population structure in a legacy collection of spring barley landraces adapted to a wide range of climates. PLoS One 9(12): e116164

Pompanon F, Bonin A, Bellemain E \& Taberlet P (2005) Genotyping errors: causes, consequences and solutions. Nat Rev Genet 6:846-847. doi: $10.1038 / \operatorname{nrg} 1707$

Rohlf F J (1998). NTSYS-pc. Numerical Taxonomy and Multivariate Analysis System. Version 2.02. Setauker, NY, USA: Exeter Pulications.

Romero M, Sanchez A M M, Pineda E, Ccamapaza Y \& Zavalla N (2019). Genetic identity based on simple sequence repeat (SSR) markers for quinoa (Chenopodium quinoa Willd.). Ciencia e Investigación Agraria 46 (2): 166-178 
Tahir N A, Omar D A, Lateef D D, Ahmad D A, Salih S H, \& Hiwa Khal L (2019). Diversity and population structure analysis of faba bean (Vicia faba L.) accessions using SSR markers. Journal of Agricultural Science and Technology 21(2): 463-474

The International Barley Genome Sequencing Consortium (2012). A physical, genetic and functional sequence assembly of the barley genome. Nature 491:711-6

Wang N, Ning S, Pourkheirandish M, Honda I \& Komatsuda T (2013). An alternative mechanism for cleistogamyin barley. Theoretical and Applied Genetics 126: 2753-2762

Weir B S (1996). Genetic Data Analysis II, $2^{\text {nd }}$ ed. Sunderland, Massachusetts, USA: Sinauer Associates Inc.

Yaldız G, Camlica M, Nadeem M A, Nawaz M A \& Baloch F S (2018). Genetic diversity assessment in Nicotiana tabacum L. with iPBSretrotransposons. Turkish Journal of Agriculture and Forestry 42: 154-164

Yeh F C, Yang R, Boyle T J, Ye Z \& Xiyan J M (2000). PopGene32, Microsoft Windows-based freeware for population genetic analysis, version 1.32. Molecular Biology and Biotechnology Centre, University of Alberta, Edmonton, Alberta, Canada.

Yıldız M, Koçak M \& Baloch F S (2015). Genetic bottlenecks in Turkish okra germplasm and utility of iPBS retrotransposon markers for genetic diversity assessment. Genetics and Molecular Research 14(3): 10588-10602

Yıldız M., Koçak M, Nadeem M A, Cavagnaro P, Barboza K, Baloch F S, Argün D \& Keleş D (2020). Genetic diversity analysis in the Turkish pepper germplasm using iPBS retrotransposon-based markers. Turkish Journal of Agriculture and Forestry 44(1): 1-14. doi:10.3906/tar-1902-10

Zhang M, Mao W, Zhang G \& Wu F (2014). Development and characterization of polymorphic EST-SSR and genomic SSR markers for Tibetan annual wild barley. PLoS ONE 9:e94881. https://doi.org/10.1371/journal.pone.0094881

(C) 2022 by the author(s). Published by Ankara University, Faculty of Agriculture, Ankara, Turkey. This is an Open Access article distributed under the terms and conditions of the Creative Commons Attribution (CC BY) license (http://creativecommons.org/licenses/by/4.0/), which permits unrestricted use, distribution, and reproduction in any medium, provided the original work is properly cited. 